through the claustrum. In this series the whole brain is included in the figures and again Horsley-Clarke reference planes are given.

The general production of the volume is good. The main features of the photographs are labelled, while the line drawings carry a more detailed indication of the various structures. Quite apart from the primary object of the book, the reproductions of the myelin-stained sections make it a valuable Atlas for comparative neurologists. It would have been even more valuable had the photographs of the cell-stained preparations been of a higher standard, but the reproductions of the frontal series are too small, and in both series contrast is poor. With this reservation, however, the volume is a useful contribution to the field of comparative and experimental neurology.

R. L. Holmes

\section{TRIBAL SOCIETY AS SEEN FROM MANCHESTER}

\section{Politics, Law and Ritual in Tribal Society}

By Prof. Max Gluckman. Pp. xxxii $+339+24$ plates. (Oxford: Basil Blackwell, 1965.) 47s. 6d. net.

$$
\mathrm{T}
$$

RIBAL society in Prof. Gluckman's new book is by and large confined to tribal Africa. This in fact constitutes a source of strength. Prof. Gluckman's chief theoretical contributions concern African societiesand this enables him to evaluate authoritatively and advocate enthusiastically the contributions of his Africanist colleagues.

Politics, Law and Ritual in Tribal Society begins with a review of the mistakes and achievements of some of the anthropological ancestors and then develops the theoretical perspective of contemporary social anthropology. Next follows a chapter on the nature of property rights and economic activity in tribal societies. This provides a background pieture for the later subject-matter of the book.

Chapters 3 and 4 are concerned with the analysis of political relations, a field in which Prof. Gluckman has made some of his best-known contributions. He elucidates the point that many societies portray conflict in their organizing principles, that in fact conflict is often an at tribute of society itself. In regard to societies which have no governmental structures he explains how conflicts are contained by a network of social ties, "so that men who are opposed to each other under one rule, are allied with each other under another rule".

The next problem taken up concerns order in societies with formal authority systems, especially those which constitute states. Some years ago he propounded the thesis of the 'rebellious cycle' and 'repetitive equilibrium', the main idea being that South African polities were held together because their territorial segments fought for a common prize, the kingship, and that rebellions produced no changes in political form. Prof. Gluckman has since advocated this thesis with decreasing conviction and increasing delimitation of the societies and time periods to which it may be applicable. In this book he describes how many or most states have frequently fragmented for many reasons, and puts forward an idea which he describes as 'akin' to that of Edmund Leach's (concerning Upper Burma) that regions of Africa have oscillated between large states and numerous small states. It may well be accepted in the future that concepts like repetitive equilibrium are rarely adequate abstractions of the actual dynamic facts.

The discussion of "Dispute and Settlement" (Chapter 5) is admittedly polemical. Prof. Gluckman demonstrates with admirable forensic skill that the forms in which disputes are expressed and the varied procedures adopted for resolving them make sociological sense only when they are related to the ranges of social relationships within which they operate. He introduces many concepts to distinguish between various kinds of dispute procedures and roles; perhaps not everyone, however, will share his enthusiasm that "specializing of the use of words out of the riches of English" will clarify our theoretical problems.

Prof. Gluckman's treatment of "Mystical Disturbance and Ritual Adjustment" (Chapter 6) is a disappointment. Following the Neo-Tylorian intellectualists, he distinguishes between 'mystical beliefs' and 'empirical beliefs', a distinction which the Western observer cannot easily make, let alone the primitive. The disappointment is not that he has made such a distinction, but that, having defined ritual in relation to mystical beliefs, he interprets it entirely in terms of its social effects. This reductionism has no bearing on the initial definition and distinctions made between ritual and ceremonial.

Furthermore, in the space of one chapter, he advances several disconnected views of ritual. The mystical definition of ritual has little bearing on the submission that ritual segregates roles and changes of roles and activities in small-scale societies with multiplex relations. Another avenue is explored when, following Victor Turner, he postulates the conditions under which judicial as opposed to ritual techniques for resolving social conflict may occur. Thus certain rituals are said to cloak fundamental disharmonies which arise out of conflicts of social principles. Turner made sense of Ndembu rituals of affliction in these terms; in trying to assimilate Turner's views to his own, Prof. Gluckman fails to achieve a marriage of ideas, for his own theory of 'rituals of rebellion' is of a different kind and tailored to fit different ethnographic facts. Finally, despite his own claims, Prof. Gluckman has not taken us any further in understanding why, in tribal societies, misfortunes are associated with the moral relations of the group concerned, why rituals which 'state conflict' indeed 'bless the moral order and its related natural order'.

A major theme that runs through the book is the developmental morphology of economic and political systems. This is dangerous ground to tread on and Prof. Gluckman once again demonstrates this. He works with an evolutionary scheme (the notion of two social types and transition from one to the other) which harks back to Maine, Durkheim, Toennies and others. Anthropologists have found such grand schemes of change descriptively true in a general sense but in practice too diffuse to explain the particular problems that engaged their attention. Prof. Gluckman's hypotheses show the same limitations. He explains the wide extension of kinship in tribal society as due to their undifferentiated economy, and its shrinkage to the differentiation in developed industrial society. But how does this formula help to account for the wide variations in kinship systems in tribal societies? How does the notion of tribal economy illuminate the widespread systems of ceremonial and economic exchange in, say, Melanesia which differ markedly from the African situation? Another hypothesis which stems from his morphological series is that rituals of rebellion (or 'role revealing rituals') associated with a particular kind of political and economic situation will be replaced by temple cults in more developed states where the existing structure of society is not accepted as hallowed. This is untenable, as a reference to temple cults in India and Ceylon will show, and is based on the misapprehension that temple cults lack "ritualisation of secular roles".

Prof. Gluckman has presented his book to the general reader as a statement "of how one social anthropologist, working in the full tradition of the subject, sees the general problem of rule and disorder in social life". Other anthropologists who also feel themselves to be in this full tradition may see certain questions differently, for this tradition is fuller and less consistent than he indicates.

S. J. TAMBIAH 